\title{
Biochar effects on methane emissions from soils: a meta- analysis
}

by Jeffery, S., Verheijen, F.G.A., Kammann, C. and Abalos, D.

Copyright, Publisher and Additional Information: This is the author accepted manuscript. The final published version (version of record) is available online via Elsevier Please refer to any applicable terms of use of the publisher.

DOI: 10.1016/j.soilbio.2016.07.021

Harper Adams

University

Jeffery, S., Verheijen, F.G.A., Kammann, C. and Abalos, D. 2016. Biochar effects on methane emissions from soils: A meta-analysis. Soil Biology and Biochemistry, 101, pp.251-258. 
1 Biochar effects on methane emissions from soils: A meta-analysis

2

3 Running title: Meta-analysis of biochar effects on $\mathrm{CH}_{4}$ flux

4

$5 \quad$ Simon Jeffery ${ }^{1 *}$

$6 \quad$ Frank G.A. Verheijen ${ }^{2}$

7 Claudia Kammann ${ }^{3}$

8 Diego Abalos ${ }^{4}$

9

101 Crop and Environment Sciences Department, Harper Adams University, Newport,

11 Shropshire, TF10 8NB, United Kingdom

122 Department of Environment and Planning, Centre for Environmental and Marine

13 Studies (CESAM), University of Aveiro, Aveiro 3810-193, Portugal

143 Department of Soil Science and Plant Nutrition, WG Climate Change Research for 15 Special Crops, Hochschule Geisenheim University, D-65366 Geisenheim, Germany

164 Department of Soil Quality, Wageningen University, P.O. Box 47, 6700 AA 17 Wageningen, The Netherlands

18

19 *sjeffery@harper-adams.ac.uk

20 Tel: +44 1952815476

21

22 Keywords

23 Biochar; methane; soil; meta-analysis; standardised mean difference; greenhouse gas.

25 Type of Paper: Research Review 


\section{Abstract}

Methane $\left(\mathrm{CH}_{4}\right)$ emissions have increased by more than $150 \%$ since 1750 , with agriculture being the major source. Further increases are predicted as permafrost regions start thawing, and rice and ruminant animal production expand. Biochar is posited to increase crop productivity while mitigating climate change by sequestering carbon in soils and by influencing greenhouse gas fluxes. There is a growing understanding of biochar effects on carbon dioxide and nitrous oxide fluxes from soil. However, little is known regarding the effects on net methane exchange, with single studies often reporting contradictory results. Here we aim to reconcile the disparate effects of biochar application to soil in agricultural systems on $\mathrm{CH}_{4}$ fluxes into a single interpretive framework by quantitative meta-analysis.

This study shows that biochar has the potential to mitigate $\mathrm{CH}_{4}$ emissions from soils, particularly from flooded (i.e. paddy) fields (Hedge's $d=-0.87$ ) and/or acidic soils (Hedge's $d=-1.56$ ) where periods of flooding are part of the management regime. Conversely, addition of biochar to soils that do not have periods of flooding (Hedge's $d=0.65$ ), in particular when neutral or alkaline (Hedge's $d=1.17$ and 0.44 , respectively), may have the potential to decrease the $\mathrm{CH}_{4}$ sink strength of those soils. Global methane fluxes are net positive as rice cultivation is a much larger source of $\mathrm{CH}_{4}$ than the sink contribution of upland soils. Therefore, this meta-study reveals that biochar use may have the potential to reduce atmospheric $\mathrm{CH}_{4}$ emissions from agricultural flooded soils on a global scale. 


\section{Introduction}

Agriculture accounts for $10-12 \%$ of total global anthropogenic emissions of greenhouse gases (GHGs), which includes $50 \%$ of global methane $\left(\mathrm{CH}_{4}\right)$ emissions (Smith et al., 2007). Methane emissions have increased by $151 \%$ since 1750 (IPCC, 2007), and are currently increasing at a rate of $0.003 \mu \mathrm{mol} \mathrm{mol}^{-1}$ year $^{-1}$ (Butenhoff and Khalil, 2007; Bloom et al., 2010). Further increases are projected due to the growing demand for food, particularly animal protein, which could require $c a .70$ million ha of additional land to fall under agricultural production (Alexandratos and Bruinsma, 2012).

Methane is primarily produced in water-logged anoxic soils by methanogenic archaea via methanogenesis (Conrad, 2007). Conversely, well-aerated upland soils are biological sinks for atmospheric $\mathrm{CH}_{4}$ (Boone et al., 1993; Dunfield, 2007). Soil $\mathrm{CH}_{4}$ uptake is driven by microbial oxidation of $\mathrm{CH}_{4}$ by methanotrophs from groups including $\alpha$ - and $\gamma$-proteobacteria, a group of obligate aerobic bacteria some of which feed solely on $\mathrm{CH}_{4}$ and others, along with genera such as Methylocella and Methylocapsa, that are facultive methanotrophs (Pratscher et al., 2011; Knief, 2015). Generally, both processes - methanogenesis and methanotropy - can occur simultaneously in micro-sites within the soil, or can be stratified with $\mathrm{CH}_{4}$ production occurring in more highly anoxic depths, and $\mathrm{CH}_{4}$ consumption occurring in overlaying oxic soil horizons. Here, the soil acts as a net source or sink depending on which is the overriding process (Hiltbrunner et al., 2012). However, these two processes can dynamically interact (Kammann et al., 2009) with $\mathrm{CH}_{4}$ consumption functioning as a "biofilter" process that can ameliorate $\mathrm{CH}_{4}$ emissions in various ecosystems, including rice paddies and landfill cover soils. 

of soil carbon (C) sequestration with soil fertility (crop yield) increases (Glaser et al., 2001; Lehmann, 2007). Initial research efforts have focused on biochar's recalcitrance as a potential means to sequester $\mathrm{C}$ in soils (Lehmann et al., 2006; Nguyen and Lehmann, 2009; Gurwick et al., 2013) while concurrently increasing crop yields (Jeffery et al., 2011). It has also been shown to mitigate nitrous oxide $\left(\mathrm{N}_{2} \mathrm{O}\right)$ emissions from agricultural soils (meta-analysis: Cayuela et al., 2014). The interactions between biochar and GHG fluxes such as carbon dioxide $\left(\mathrm{CO}_{2}\right)$ and $\mathrm{N}_{2} \mathrm{O}$, and the associated mechanisms, are becoming better understood (Cayuela et al., 2013; Maestrini et al., 2014; Cayuela et al., 2015; Obia et al., 2015; Sagrilo et al., 2015). However, there is still a paucity of information on $\mathrm{CH}_{4}$ flux effects beyond the single study scale, which often report contradictory results.

Biochar has been shown to increase (Zhang et al., 2010; Spokas et al., 2011), effect (Kammann et al., 2012) on $\mathrm{CH}_{4}$ emissions from soils. Mechanisms are usually only assumed or hypothesised and remain unclear. Meta-analysis is a useful tool for comparing results across studies to reveal common response patterns. It facilitates extrapolation of results and formulation of mechanistic hypotheses (e.g. within the same soil conditions; or with the same biochar types) and thus increases the robustness of extrapolations and predictions across systems.

The mechanisms by which biochar may affect soil $\mathrm{CH}_{4}$ fluxes include sorption of $\mathrm{CH}_{4}$ to biochar's surfaces (Yaghoubio et al., 2014), and soil aeration by biochar addition, which may increase diffusive $\mathrm{CH}_{4}$ uptake (van Zwieten et al., 2010; Karhu et al., 2011), as microbial $\mathrm{CH}_{4}$ oxidation in upland soils is mostly substrate-limited (Castro et al., 1994). However, in anoxic environments, the labile $\mathrm{C}$ pool of biochar may 
97 function as methanogenic substrate, promoting $\mathrm{CH}_{4}$ production (Wang et al., 2012).

98 Biochar has also been shown to promote methanotrophic $\mathrm{CH}_{4}$ consumption at 99 oxic/anoxic interfaces in anoxic environments, lowering $\mathrm{CH}_{4}$ emissions via the

100 "biofilter" function of $\mathrm{CH}_{4}$ consumption (Feng et al., 2012; Reddy et al., 2014).

101 A recent work has also included meta-analysis of $\mathrm{CH}_{4}$ emissions in response to

102 biochar application as part of a wider analysis (Song et al., 2016). However, the method 103 applied in their analysis does not allow the inclusion of negative fluxes (i.e. all $\mathrm{CH}_{4}$ 104 sinks) and thus was restricted in the conclusions that could be drawn. Here, we present 105 the first comprehensive meta-analytical investigation of the effects of biochar 106 application to soil in agricultural systems on $\mathrm{CH}_{4}$ emissions drawing on studies with a 107 global distribution.

108

\section{Material and Methods}

\subsection{Data collection and categorisation}

111 The keywords "biochar" AND "methane" $\mathrm{OR}$ " $\mathrm{CH}_{4}$ " were entered into the search

112 engines of Scopus, Web of Science and Google Scholar to identify relevant studies for 113 inclusion in the meta-analysis. This led to identification of 62 studies, to a cut-off date 114 of $31^{\text {st }}$ December 2014. Studies were vetted using inclusion criteria consisting of 115 studies: (i) using a randomised design; (ii) using replicated samples per treatment; and 116 (iii) containing a "treatment" and "control" such that the treatment was the same as the 117 control in all aspects apart from the inclusion of biochar. Only cumulative net $\mathrm{CH}_{4}$ 118 fluxes were included. Where only daily or seasonal fluxes were reported, corresponding 119 authors were contacted to ask for data on cumulative fluxes and means. When these 120 data were provided the studies where included; otherwise they were excluded. Of the 
121 total studies, 42 met the inclusion criteria (Table S1), from which 189 pairwise comparisons were extracted.

Data were collected from tables presented in manuscripts where possible, or

124 from figures using Plot Digitizer 2.6.6 (Huwaldt, 2015) or Web Plot Digitizer (Rohatgi, 125 2016), or from authors directly. Error bars were usually present in the form of standard 126 errors; standard deviations were back calculated from these when necessary. When no measure of variance was available, corresponding authors were contacted to obtain such information. Categorical information concerning biochar, soil and environmental

129 properties was also collected from manuscripts and recorded as auxiliary variables.

130 These can be found in the full database which is available in supplementary 131 information.

Auxiliary variables were grouped to facilitate cross-comparisons between

133 studies using the same groupings as Cayuela et al. (2014). These variables related to 134 soil $\mathrm{pH}$ grouped to $<6$ and $6-8$ and $>8$ representing the optimum $\mathrm{pH}$ range for 135 methanogenesis and methanotrophy; biochar feedstock, grouped as Manure - manures 136 or manure-based materials from poultry, pig or cattle), Wood - oak, pine, willow, 137 sycamore and unidentified wood mixtures, Herbaceous - greenwaste, bamboo, maize 138 stover, straws; Biosolids - sewage sludge from water treatment plants and

139 lignocellulosic wastes - including rice husk, nuts shells, paper mill waste; pyrolysis 140 temperature, grouped as $<450^{\circ} \mathrm{C} 450-600$ and $>600^{\circ} \mathrm{C}, H: C_{\text {org }}$, grouped as $<0.30 .3-$ $1410.5>0.5$; Brunauer, Emmett and Teller (BET) surface area $\left(\mathrm{m}^{2} \mathrm{~g}^{-1}\right)$, grouped as $<100$, $142 \quad 100-500$ and >500; water regime, water regime, grouped as Flooded (paddy soils and 143 studies conducted under continuous waterlogged conditions), Cycles (paddy soils 144 involving flooding-drying in which $\mathrm{CH}_{4}$ emissions were measured during both the wet 145 and dry periods) and Non-Flooded (studies were flooding was not part of the 
146 experimental setting); and $\mathrm{N}$ and Phosphorus (P) fertilization, grouped by rate for $\mathrm{N}$, $147 \leq 120 \mathrm{~kg} \mathrm{~N} \mathrm{ha}^{-1}$ and $>120 \mathrm{~kg} \mathrm{~N} \mathrm{ha}^{-1}$, and as $\mathrm{P}$ or No P if $\mathrm{P}$ fertilizer was applied or not 148 for P respectively.

\subsection{Meta-analytical metric} sources (positive values, emissions). The notation of the flux direction follows the convention by biogeochemists and takes the view from the atmosphere that gains or

154 loses the gas in question. Since it is not possible to take a logarithm of a negative number, this precludes the use of the response ratio (calculated as the natural log of the experimental mean over the control mean) as a metric for comparison between studies, which is considered the preferred metric for ecological studies (Hedges et al., 1999).

158 Here we utilise the standardised mean difference metric "Hedge's $d$ " for analysis 159 (Equation 1; Hedges and Olkin, 1985). This is a less biased indicator than "Hedge's $g$ " 160 (Equation 2; Hedges, 1981; Hedges and Olkin, 1985). Note that this is a different 161 standardised mean difference metric to "Cohen's $d$ " which was developed for 162 behavioural science (Cohen, 1988); Hedge's $d$ is less biased by small sample sizes 163 (Hedges and Olkin, 1985) and was used as this was the case for most studies included 164 in this meta-analysis.

165

166 Equation 1

$$
d=\left(1-\frac{3}{4(n-2)-1}\right) g
$$

168 Where $n$ is the total sample size on which $g$ is based, and $g$ is Hedge's $g$ as calculated 169 by Equation 2 
171 Equation 2

$$
g=\frac{\bar{x}_{1}-\bar{x}_{2}}{s}
$$

172

173 Where $\bar{x}_{1}$ and $\bar{x}_{2}$ are the experimental and control means and $s$ is the pooled standard 174 deviation.

Here, experimental treatment refers to the treatment with biochar - controls are

176 samples that are the same in all aspects, including any other amendment, without 177 addition of biochar. A categorical random effects model was applied to $d$, with means 178 weighted by the inverse of the variance. Confidence intervals (95\%; CIs) were 179 generated by bootstrapping (9999 iterations). To obtain a standardised mean effect size, 180 the effect size was then divided by an estimate of the standard deviation of the effect 181 sizes (Hedges and Olkin, 1985). Input data were arranged in Microsoft Excel 2010. 182 Calculations were performed using Metawin Version 2 statistical software (Rosenberg 183 et al., 2000).

184 The interpretation of the standardised mean effect size differs from the response 185 ratio as it cannot be expressed as a percent change in response of an experimental 186 treatment compared to a control. Rather, it is equivalent to a $Z$-score and as such 187 represents the number of standard deviations that the standardised mean of the 188 experimental treatment is from the standardised mean of the control. The effect of a 189 response variable can be considered significant if the $95 \%$ CI does not intersect the 190 standardised control mean (i.e. Z-value $=0$ ). Groupings of auxiliary variables are 191 considered significantly different if their $95 \%$ CIs do not overlap. 


\subsection{Interpretation of standardised mean effect size}

There is no rigorously applied framework for interpretation of standardised means in terms of "effect sizes" because, unlike response ratios, they are probabilistic. That is, they describe the probability that a sample drawn from the control treatments would fall between the experimental mean and the control mean, assuming a normal distribution. By convention, a large effect is indicated by $d>0.8$, a moderate effect by $d=0.2-0.8$, and a small effect by $d=0-0.2$ (Cohen, 1988; Gurevitch et al., 1992). However, it is generally acknowledged that these terms are relative and likely dependent on research area and methods (Hedges, 1981). A key point is that, using this metric, an effect size of (for example) 0.2 for a category does not equate to an effect size of 0.2 for categories in independent analyses presented in this paper, in absolute terms. Only categories within individual analyses, as differentiated by the horizontal dotted bars in Fig. 1 and 2, can be compared relatively (i.e. only within each category does an effect size of 0.4 equate to twice the size of 0.2 ; comparisons between figures are qualitative only). Further, small effect sizes ( $\sim 0.2)$ may indicate significant changes in cumulative GHG fluxes, in absolute terms, particularly if effects persist over the long lifetime of biochar. Data are presented in two figures to allow use of different scale $\mathrm{x}$ axis only and does not represent any fundamental difference in analyses.

Interpretation of effect sizes here is further confounded by the $\mathrm{CH}_{4}$ sink/source flux direction in soils. A positive effect size implies a shift to the right on a scale going from strong net sink (i.e. negative flux values) to strong net source (i.e. positive flux values). However, it does not necessarily mean a change has occurred in the net sink/source status of the soil. Rather, it signifies that either the net sink strength has decreased, the soil has switched from sink to source, or that the net source strength has increased - and vice versa for negative effect sizes. 
We tested the effects of publication bias using the Fail-safe $N$ technique (Orwin,

221 1983; Rosenthal and Rosnow, 1991). A weakness with meta-analyses of experimental 222 studies is that several experimental treatments are often compared to a single (identical) 223 control in a published study. This artificially increases the number of replicate pairs and 224 violates the assumption of independence that the effect size metric is based upon; the 225 controls are necessarily counted repeatedly in pairwise control versus experimental 226 treatment comparisons. Means of controlling for this bias (Borenstein et al., 2009; 227 Aguilera et al., 2013) often show little effect (van Groenigen et al., 2006; Gattinger et 228 al., 2012; Abalos et al., 2014; Skinner et al., 2014). Therefore, we here report results 229 from the analysis on the level of single comparisons. 


\section{Results}

Figure 1 shows the effect of biochar application to soils under different

234 irrigation regimes. Biochar addition to Flooded soils (as part of their management 235 practice) significantly increased in $\mathrm{CH}_{4}$ sink strength / reduced source strength 236 compared to Flooded soils without biochar application (Hedge's $d=-0.87$ ). Studies 237 reporting biochar additions to Non-Flooded soils showed an overall moderate but 238 significant decrease in the $\mathrm{CH}_{4}$ sink strength / increase in source strength (Hedge's $d=$ 239 0.65). Experiments in which irrigation was applied as Cycles of flooding and draining 240 did not show a significant response to biochar application.

241 Biochar application to acidic soils (i.e. with a $\mathrm{pH}<6$ ) resulted in the strongest 242 effect size, causing a statistically significant increase in $\mathrm{CH}_{4}$ sink strength / decrease in 243 source strength following biochar application (Hedge's $d=-1.56$; Fig. 1). Conversely, 244 addition of biochar to soils within the neutral $\mathrm{pH}$ range (i.e. 6-8) showed a statistically 245 significant decrease in $\mathrm{CH}_{4}$ sink strength / increase in source strength (Hedge's $d=$ 246 1.17). Application of biochar to soils with a $\mathrm{pH}$ greater than 8 did not show a 247 statistically significant response to biochar application.

248 Biochar effects on $\mathrm{CH}_{4}$ flux interact with $\mathrm{N}$ fertilizer rate (Fig. 1). Application 249 of $\mathrm{N}$ fertilizers at rates less than $120 \mathrm{~kg} \mathrm{ha}^{-1}$ caused a strong and statistically significant 250 increase in $\mathrm{CH}_{4}$ sink strength / decrease in source strength in the presence of biochar 251 (Hedge's $d=-3.1$ ). Applications of $\mathrm{N}$ fertilizer at higher rates showed no interaction 252 with biochar on soil $\mathrm{CH}_{4}$ fluxes.

Biochars produced at high temperatures caused a statistically significant 254 increase in $\mathrm{CH}_{4}$ sink strength / reduction in source strength following application to 255 soils (Hedge's $d=-1.3$; Fig. 1). Mid-temperature biochars $\left(450-600^{\circ} \mathrm{C}\right.$ ) led to 
significant reductions in $\mathrm{CH}_{4}$ sink strength / increased source strength when applied to soil (Hedge's $d=0.67$ ).

In terms of interactions with feedstock source, biochar produced from biosolids

259 led to a statistically significant increase in sink strength / reduction in source strength

260 (Hedge's $d=-6.03$; Fig. 2). When produced from Lignocellulosic waste, biochar 261 significantly decreased the $\mathrm{CH}_{4}$ sink strength / increased the source strength (Hedge's $d=0.74)$. No other feedstock showed statistically significant effects on $\mathrm{CH}_{4}$ fluxes.

No significant effects or differences between sub-groups were found for the category BET Surface Area; however, there was an apparent trend whereby increased BET surface area resulted in increasing sink strength / decreased source strength (Fig. 2).

\section{Discussion}

Using standardised mean differences as the meta-analysis metric precludes making

270 firm conclusions in terms of changes in $\mathrm{CH}_{4}$ sink/source functioning. A statistical 271 approach based on measurements of net $\mathrm{CH}_{4}$ fluxes alone does not enable differentiation between changes in methanogenesis or methanotrophy. However, it can

273 identify the effect of biochar on the direction of net $\mathrm{CH}_{4}$ fluxes (i.e. changes in overall 274 sink/source strength). It also allows identification of the key management practices and 275 soil and biochar properties which likely underlie the observed effects, and since the 276 "usual" $\mathrm{CH}_{4}$ flux direction in flooded wetland or aerated upland soils is known in 277 general, the results provide first general insights into associated factors that need further 278 investigation.

279 Application of biochar to soil produced a range of effects on $\mathrm{CH}_{4}$ fluxes across 280 studies, as expected. In most instances the "Grand Mean" (i.e. the mean response of all 
281 studies combined) was not significantly different to the control. This result is most 282 likely due to contrasting responses (i.e. positive and negative effects on net $\mathrm{CH}_{4}$ fluxes) 283 cancelling each other out when studies assigned to all functional categories were 284 combined. The data are unlikely to be significantly affected by publication bias, as 285 studies finding either a positive or negative result are equally publishable, and most 286 studies also investigated other factors such as $\mathrm{N}_{2} \mathrm{O}$ fluxes and/or yield response. These 287 have been shown to have a positive response to biochar application (Cayuela et al., 288 2014; Jeffery et al., 2011). As such, studies also investigating these metrics would have 289 an increased chance of publication of the "associated" $\mathrm{CH}_{4}$ flux results.

\subsection{Irrigation management}

Biochar addition to soils that were flooded as part of their management practice significantly increased $\mathrm{CH}_{4}$ sink strength / reduced source strength compared to their controls. Methanogenesis is an exclusively anaerobic process (Thauer, 1998). Here (Flooded; Fig. 1), the change in $\mathrm{CH}_{4}$ flux would likely equate to reduced net $\mathrm{CH}_{4}$ emissions from flooded paddy soils, indicating that either the production decreased or methanotrophy in the rhizosphere increased through influencing the methanogenic/methanotrophic ratio of soils. Feng et al. (2012) reported that biochar

299 decreased the ratio of methanogenic archaea to methanotrophic bacteria. In flooded 300 soils, $\mathrm{CH}_{4}$ consumption occurs at the aerated root interface where most $\mathrm{CH}_{4}$ produced 301 in the surrounding anoxic sediment usually enters the aerenchymatic root-shoot rice 302 tissue, leaving the soil via this plant 'chimney'. Thus, increased $\mathrm{CH}_{4}$ oxidation at the 303 "biofilter" anoxic/oxic interface may explain the apparent $\mathrm{CH}_{4}$ efflux mitigation 304 potential of biochar application to flooded soils observed in our meta-analysis. Other 305 studies in paddy soils (Liu et al., 2011; Singla et al., 2014) found no significant effects 
on methanogenic archaeal diversity between biochar treated and non-treated soils (but did not investigate $\mathrm{CH}_{4}$ oxidizer communities).

Non-flooded (i.e. predominantly oxic) upland soils are an important sink for $\mathrm{CH}_{4}$ and are considered to contribute to approximately $15 \%$ of global $\mathrm{CH}_{4}$ oxidation

310 (Powlson et al., 1997). Figure 1 suggests that biochar application may decrease net $\mathrm{CH}_{4}$ 311 oxidation by such soils. As intensively managed agricultural soils are relatively poor 312 sinks of $\mathrm{CH}_{4}$, it is likely that the decrease in net $\mathrm{CH}_{4}$ efflux from Flooded soils more 313 than counteracts any decrease in the net uptake from Non-flooded soils. Therefore, 314 biochar use in rice agriculture may contribute to reducing the $\mathrm{C}$ footprint of rice 315 production, which is usually worse than for example that of wheat production due to 316 the $\mathrm{CH}_{4}$ emission burden.

318 did not show a significant response to biochar application. However, considerably 319 fewer pairwise comparisons contributed to this category: 14 compared to 56 for 320 Flooded and 85 for Non-Flooded. As such, there is reduced confidence in this result 321 evidenced by the relatively large error bars (Fig. 1). All studies included in this analysis were conducted in managed systems: either 323 in the field or in controlled laboratory or greenhouse experiments. Currently, there is 324 no work in the published literature that has investigated biochar effects when applied 325 to natural wetlands, such as marshes, bogs and swamps, which can be significant 326 sources of $\mathrm{CH}_{4}$ emission (Bubier and Moore, 1994). This represents an unknown area 327 of biochar research that may grow in importance as novel biochar applications are 328 sought and potentially the biochar load of these systems increases due to biochar 329 transport over time through waterways following erosion events (Jaffé et al., 2013). 
Soil $\mathrm{pH}$ is one of the main environmental parameters that affects both 333 methanogenesis and methanotrophy (Hanson and Hanson, 1996; Semrau et al., 2010). 334 The optimum $\mathrm{pH}$ range of most methanogens ranges from 6 to 8 (Garcia et al., 2000), 335 thereby overlapping with the optimum $\mathrm{pH}$ range for methanotrophy, which also extends 336 to more acidic conditions (Le Mer and Roger, 2001; Semrau et al., 2010). Biochar generally has a higher $\mathrm{pH}$ than the soil to which it is applied, thereby providing a liming 338 effect (Chidumayo, 1994; Yamato et al., 2006; Jeffery et al., 2011); the pairwise comparisons of this meta-analysis have an average $\mathrm{pH}$ of 6.2 for soil and 9.6 for biochar.

340 As the optimum $\mathrm{pH}$ range for both methanogenesis and methanotrophy is similar, it 341 may be expected that raising the soil $\mathrm{pH}$ to within the optimum range would affect both 342 processes equally. However, we observed a significant increase in $\mathrm{CH}_{4}$ sink strength / 343 decrease in source strength for acidic soils (Fig. 1). A potential explanation is that the 344 size and/or structure of methanotrophic communities may be more sensitive to rising 345 soil $\mathrm{pH}$ than that of methanogens. Experiments quantifying, for example, the $346 \mathrm{mcr} / \mathrm{pmoA}$ ratios of soils are required to identify the cause underlying this observed 347 effect.

348 Another possible explanation for the large $\mathrm{CH}_{4}$ mitigating effect of biochar in 349 acidic soils is related to $\mathrm{Al}^{3+}$ toxicity. Soils with a low $\mathrm{pH}$ are associated with increased $350 \mathrm{Al}^{3+}$ solubility, which is highly toxic for methanotrophic bacteria (Tamai et al., 2007). 351 By increasing soil $\mathrm{pH}$, biochar may reduce $\mathrm{Al}^{3+}$ release from cation exchange sites in 352 the soil, thereby reducing toxicity levels for methanotrophs. A further analysis of initial 353 soil $\mathrm{pH}$ effects on $\mathrm{CH}_{4}$ fluxes, utilising a cut off at a $\mathrm{pH}$ of 5, the threshold above which $354 \mathrm{Al}^{3+}$ availability strongly decreases, provides further evidence for this explanation (Fig. 355 S1). Biochar applied to soils with a $\mathrm{pH}<5$ showed a significant increase in sink strength 
356 / reduction in source strength compared to soils with a $\mathrm{pH}>5$. When biochar was 357 applied to soils already above this threshold, no significant effect on $\mathrm{CH}_{4}$ flux was 358 observed. This hypothesis is in line with the literature on this topic (reviewed in 359 Dunfield 2007; e.g. Sitaula \& Bakken 2001) but more empirical studies are required to 360 confirm or reject this hypothesised mechanism.

\section{3. $N$ Fertilizer}

Figure 1 suggests that when biochar is applied with $<120 \mathrm{t} \mathrm{ha}^{-1} \mathrm{~N}$ fertilizer, it

364 can reduce $\mathrm{CH}_{4}$ fluxes, while it has no effect when applied with $>120 \mathrm{t} \mathrm{ha}^{-1} \mathrm{~N}$. However, 365 the effect of $\mathrm{N}$ fertilizer type and application rate on $\mathrm{CH}_{4}$ flux is, in general, highly 366 controversial. In soils where methanotroph $\mathrm{N}$ supply is not limiting to growth and 367 activity, it is generally expected that the addition of $\mathrm{NH}_{4}{ }^{+}$-containing or delivering 368 fertilizers will lead to decreased $\mathrm{CH}_{4}$ oxidation due to competitive exclusion of $\mathrm{CH}_{4}$ at 369 binding sites by $\mathrm{NH}_{4}{ }^{+}$(Bédard and Knowles, 1989; Sylvia et al., 2005). However, this 370 effect is rate dependent; smaller amounts of $\mathrm{N}$ tend to stimulate $\mathrm{CH}_{4}$ uptake while larger 371 amounts tend to inhibit uptake into the soil (Aronson and Helilker, 2010). Despite this 372 general rule, in severely $\mathrm{N}$-limiting environments, the addition of an $\mathrm{N}$ source, even $373 \mathrm{NH}_{4}{ }^{+}$which may also competitively inhibit $\mathrm{CH}_{4}$ oxidation (Bedard and Knowles 1989;

374 Gulledge et al., 1997), can lead to an increase in $\mathrm{CH}_{4}$ oxidation due to an increase in 375 methanotrophic biomass (Bodelier et al., 2000; Nazaries et al., 2013). The switch 376 between stimulation and inhibition of $\mathrm{CH}_{4}$ uptake has been reported to occur at between $377100 \mathrm{~kg} \mathrm{~N} \mathrm{ha}^{-1}$ (Aronson and Helilker, 2010) and $140 \mathrm{~kg} \mathrm{~N} \mathrm{ha}^{-1}$ (Banger et al., 2012). 378 As such, we set the threshold for our analysis to the mid-point between these studies $379120 \mathrm{~kg} \mathrm{~N} \mathrm{ha}^{-1}$ (Fig. 1). This analysis shows that when $\mathrm{N}$ is applied above this threshold 380 there is no significant difference between the experimental treatments (with biochar) 
381 and the controls (without biochar). When biochar is applied with levels of $\mathrm{N}$ below the 382 threshold a significant difference is observed between the experimental treatments 383 (with biochar) and the controls (without biochar) with increased sink strength/ reduced 384 source strength being observed following biochar application with $\mathrm{N}$ fertilization rates 385 below $120 \mathrm{k} \mathrm{N} \mathrm{ha}^{-1}$. The mechanism for this response pattern when biochar is applied 386 with low $\mathrm{N}$ rates remains unclear and warrants further investigation

\subsection{Pyrolysis temperature}

Biochars produced at high temperatures caused a statistically significant increase in $\mathrm{CH}_{4}$ sink strength / reduction in source strength following application to soils (Fig. 1). High temperature biochars are characterised by fewer labile compounds remaining on the surface of biochar particles, and so introduce less microbial substrate than lower temperature biochars when applied to soil (Brunn et al., 2011).

Reduced $\mathrm{H}: \mathrm{C}_{\text {org }}$ ratios in high temperature biochars indicate increased aromaticity, which is associated with the reducing effect of biochar on $\mathrm{N}_{2} \mathrm{O}$ emissions (Cayuela et al., 2015). However, we did not find any relationship between $\mathrm{H}: \mathrm{C}_{\text {org }}$ and

$399 \mathrm{CH}_{4}$ fluxes from soil (Fig. S2).

Mid-temperature biochars $\left(450-600^{\circ} \mathrm{C}\right)$ led to significant reductions in $\mathrm{CH}_{4}$ sink 401 strength / increased source strength when applied to soil (Fig. 1). The majority (73\%) 402 of the studies that used mid-temperature biochar were performed on non-flooded soils. 403 This means that there is a confounding effect: it may be that the effect observed here is 404 due to either biochar properties or soil water management - it is not possible to 405 distinguish between the two with the analysis used for this study. 
In general, the feedstock from which biochar was produced did not lead to

409 significantly different effect on $\mathrm{CH}_{4}$ flux, with the exception of biosolids (Fig. 2). The 410 effect size for biochar produced from biosolids is remarkably large (Hedges, 1981), as 411 are the associated confidence intervals. This may be exacerbated by the low number of 412 pairwise comparisons on which the statistic is based; all of the four pairwise 413 comparisons were drawn from one study (Khan et al., 2013). The biochar used for this 414 study was produced from sewage sludge (here grouped as Biosolids; according to 415 Cayuela et al., 2014) and was applied to very acidic soil (i.e. $\mathrm{pH}=4.02$ ). Possible 416 mechanisms, as discussed above, include potential changes in the size and/or structure 417 of methanotrophic communities, or potentially reduced $\mathrm{Al}^{3+}$ toxicity effects. In 418 addition, the effect may also be partly due to the high sulphur content of this feedstock 419 (5.3\% dry weight). This hypothesis is consistent with previous results that showed 420 decreased $\mathrm{CH}_{4}$ emissions when ammonium sulphate was used as a fertilizer compared 421 to urea (Bufogle et al., 1998).

Biochar produced from Lignocellulosic waste led to a significantly decreased

$423 \mathrm{CH}_{4}$ sink strength / increased source strength. The mechanism underlying this effect 424 remains unclear and warrants further research.

\subsection{BET Surface Area}

Biochar production temperature and the Brunauer, Emmett and Teller (BET) surface area of biochars have been shown to be positively correlated (Ronsse et al., 429 2013; Kambo and Dutta, 2015). This suggests that adsorption of $\mathrm{CH}_{4}$ to the surface of 430 biochars (Sadasivam and Reddy, 2014) may also be responsible for the reduced flux in 
431 the high temperature biochars (Fig. 1). However, this characteristic is often not reported

432 in biochar studies, which hinders investigation of this potential mechanism. It appears

433 that there is a trend whereby increased BET surface area results in decreased $\mathrm{CH}_{4}$ flux

434 (Fig. 2). However, the data are highly variable in the highest category (>500) with little

435 confidence in the mean value owing to the low number of pairwise comparisons on

436 which this statistic is based $(n=3)$. More studies using high surface area biochars, or 437 systematically varying BET, are needed to investigate the importance of $\mathrm{CH}_{4}$ or 438 inhibitory $\mathrm{N}$ adsorption onto biochar as a mechanism underlying observed reductions 439 in $\mathrm{CH}_{4}$ fluxes.

\section{Conclusions}

Evidence presented in this study shows that biochar does have the potential to mitigate $\mathrm{CH}_{4}$ emissions from soil, particularly from paddy fields and/or acidic soils that use periods of flooding as part of their management regime. However, addition of biochar to neutral or alkaline soils that do not have periods of flooding, may have the potential to decrease the $\mathrm{CH}_{4}$ sink strength of those soils. These results indicate that soil and biochar properties, as well as management conditions, must be considered to maximise biochar's potential to mitigate $\mathrm{CH}_{4}$ emissions and minimise trade-offs.

450 characteristics of biochar properties. Biochar $\mathrm{pH}$ has been shown to be highly pertinent

451 for predicting response of some ecosystem functions to biochar application, in both this 452 current study and previous studies (Jeffery et al., 2011; Sagrilo et al., 2015). Other 453 functional characteristics (or proxies thereof) such as the molar $\mathrm{H}: \mathrm{C}_{\text {org }}$ ratio are 454 becoming more recognised as effective predictors (Cayuela et al., 2015). Here we show 455 that BET surface area may be an important functional characteristic in terms or 
predicting $\mathrm{CH}_{4}$ flux mitigation potential of biochar. However, insufficient numbers of experiments have reported the characteristic to draw firm conclusions. It is vital that

458 biochar researchers characterise and report functional characteristics of their biochars 459 wherever possible.

460 Finally, it is apparent that trade-offs are inevitable and clear goals are necessary 461 before effective advice can be offered to land managers and policy makers (Jeffery et 462 al., 2015). For example, low temperature, slow pyrolysis maximises biochar production 463 (Sohi et al., 2010) and thereby also C sequestration potential. However, evidence 464 presented in this study shows that high temperature biochars are more effective at 465 mitigating $\mathrm{CH}_{4}$ emissions (the same applies for $\mathrm{N}_{2} \mathrm{O}$, Cayuela et al., 2015). Which one 466 has the greatest potential to mitigate climate change thus remains to be determined and 467 will require life cycle assessment approaches. However, market forces are likely to 468 make the former more attractive until the full environmental costs of production are 469 included as part of agricultural products. 


\section{Acknowledgements}

472 We gratefully acknowledge funding from Marie Curie CIG grant (No. GA 473 526/09/1762). Simon Jeffery was also supported by funding under the Emerging 474 Science Theme of the Graduate School Production Ecology and Resource Conservation 475 of Wageningen UR. We thank the Portuguese Fundação para a Ciência e a Tecnologia 476 (FCT) for providing Frank G. A. Verheijen with a postdoctoral grant 477 (SFRH/BPD/74108/2010). Diego Abalos is supported by a Marie Skłodowska-Curie 478 Individual Fellowship under Horizon 2020 (No. GA 656632). Claudia Kammann 479 acklnowledges DFG grant KA3442/1-1 that allowed her to carry on biochar research 480 and gain new insights into biochar- $\mathrm{N}$ interactions. 


\section{References}

484

485

486

487

488

489

490

491

492

493

494

495

496

497

498

499

500

501

502

503

Abalos, D., Jeffery, S., Sanz-Cobena, A., Guardia, G., Vallejo, A., 2014. Meta-

analysis of the effect of urease and nitrification inhibitors on crop productivity and

nitrogen use efficiency. Agriculture, Ecosystems and Environment 189, 136-144.

Aguilera, E., Lassaletta, L., Sanz-Cobena, A., Garnier, J., Vallejo, A., 2013. The potential of organic fertilizers and water management to reduce $\mathrm{N}_{2} \mathrm{O}$ emissions in Mediterranean climate cropping systems. A review. Agriculture, Ecosystems and Environment, 164, 32-52.

Alexandratos, N., Bruinsma, J., 2012. World agriculture towards 2030/2050: the 2012 revision. ESA Working paper No. 12-03. FAO, Rome, Italy.

Ali M.A., Hoque, M.A., Kim, P.J. 2013. Mitigating global warming potentials of methane and nitrous oxide gases from rice paddies under different irrigation regimes. Ambio, 42, 357-368.

Aronson, E.L., Helliker, B.R., 2010. Methane flux in non-wetland soils in response to nitrogen addition: a meta-analysis. Ecology, 91, 3242-3251.

Asai, H., Samson, B.K., Stephan, H.M., Songyikhangsuthor, K., Homma, K., Kiyono, Y., Inoue, Y., Shiraiwa, T., Horie, T., 2009. Biochar amendment techniques for upland rice production in Northern Laos: 1. Soil physical properties, leaf SPAD and grain yield. Field Crops Research, 111, 81-84.

Banger, K., Tian, H., Lu, C., 2012. Do nitrogen fertilizers stimulate or inhibit methane emissions from rice fields? Global Change Biology, 18, 3259-3267. 
504 Basso, A.S., Miguez, F.E., Laird, D.A., Horton, R., Westgate, M., 2013. Assessing 505 potential of biochar for increasing water-holding capacity of sandy soils. GCB 506 Bioenergy, 5, 132-143.

507 Bédard, C., Knowles, R., 1989. Physiology, biochemistry, and specific inhibitors of $508 \mathrm{CH} 4, \mathrm{NH} 4+$ and $\mathrm{CO}$ oxidation by methanotrophs and nitrifiers. Microbiological 509 Reviews, 53, 68-84.

510 Bloom, A.A., Palmer, P.I., Fraser, A., Reay, D.S., Frankenberg, C., 2010. Large-scale 511 controls of methanogenesis inferred from methane and gravity spaceborne data. 512 Science, 327, 322-325.

513 Bodelier, P.L.E., Roslev, P., Henckel, T., Frenzel, P., 2000. Stimulation by ammonium514 based fertilizers of methane oxidation in soil around rice roots. Nature, 403, 421-424.

515 Boeckx, P., Van Cleemput, O., Villaralvo, I., 1997. Methane oxidation in soils with 516 different textures and land use. Nutrient Cycling in Agroecosystems, 49, 91-95.

517 Boone, D.R., Whitman, W.B., Rouviere, P., 1993. Diversity and taxonomy of 518 methanogens. Methanogenesis. Ecology, Physiology, Biochemistry and Genetics. 519 Chapman and Hall, New York, 35-80.

520 Borenstein, M., Hedges, L.V., Higgins, J.P.T., Rothstein, H.R., 2009. Introduction to 521 Meta-Analysis. Wiley, Chichester, UK.

522 Bruun, E.W., Hauggaard-Nielsen, H., Ibrahim, N., Egsgaard, H., Ambus, P., Jensen, 523 P.A., Dam-Johansen, K., 2011. Influence of fast pyrolysis temperature on biochar labile 524 fraction and short-term carbon loss in a loamy soil. Biomass and Bioenergy, 35, 11825251189. 
Bubier, J.L., Moore, T.R., 1994. An ecological perspective on methane emissions from northern wetlands. Trends in Ecology and Evolution, 9, 460-464.

Bufogle, A., Bollich, P.K., Kovar, J.L., Lindau, C.W., Macchiavellid, R.E., 1998. Comparison of ammonium sulphate and urea as nitrogen sources in rice production. Journal of Plant Nutrition, 21, 1601-1614.

531 Butenhoff, C.L., Khalil, M.A.K., 2007. Global methane emissions from terrestrial 532 plants. Environmental Science and Technology, 41, 4032-4037.

533 Ciais, P., Sabine, C., Bala, G., Bopp, L., Brovkin, V., Canadell, J., Chhabra, A., 534 DeFries, R., Galloway, J., Heimann, M., Jones, C., Le Quéré, C., Myneni, R.B., Piao, 535 S., Thornton, P., 2013. Carbon and Other Biogeochemical Cycles. In: Stocker, T.F., 536 Qin, D., Plattner, G.K., Tignor, M., Allen, S., Boschung, J., Nauels, A., Xia, Y., Bex, 537 V., Midgley, P.M., (Eds.) Climate Change: The Physical Science Basis. Contribution 538 of Working Group I to the Fifth Assessment Report of the Intergovernmental Panel on 539 Climate Change. Cambridge University Press, Cambridge, United Kingdom and New 540 York, NY, USA.

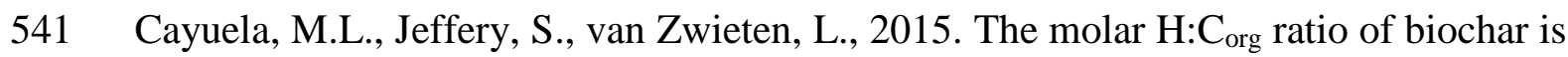
542 a key factor in mitigating $\mathrm{N}_{2} \mathrm{O}$ emissions from soil. Agriculture, Ecosystems and 543 Environment, 202, 135-138.

544 Cayuela, M.L., Sánchez-Monedero, M.A., Roig, A., Hanley, K., Enders, A., Lehmann, 545 J., 2013. Biochar and denitrification in soils: when, how much and why does biochar 546 reduce $\mathrm{N}_{2} \mathrm{O}$ emissions? Scientific Reports, 3, 1732. 
547 Cayuela, M.L., van Zwieten, L., Singh, B.P., Jeffery, S., Roig, A., Sánchez-Monedero, 548 M.A., 2014. Biochar's role in mitigating soil nitrous oxide emissions: A review and 549 meta-analysis. Agriculture, Ecosystems and Environment, 191, 5-16.

550 Chidumayo, E.N., 1994. Effects of wood carbonization on soil and initial development 551 of seedlings in miombo woodland, Zambia. Forest Ecology and Management, 70, 353552357.

553 Cohen, J., 1988. Statistical Power Analysis for the Behavioral Sciences. Lawrence 554 Erlbaum Associates, New Jersey.

555 Conrad, R., 2007. Microbial ecology of methanogens and methanotrops. Advances in 556 Agronomy, 96, 1-8.

557 Cornelissen, G., Gustafsson, Ö., Bucheli, T.D., Jonker, M.T.O., Koelmans, A.A., van 558 Noort, P.C.M., 2005. Extensive sorption of organic compounds to black carbon, coal, 559 and kerogen in sediments and soils: Mechanisms and consequences for distribution, 560 bioaccumulation, and biodegradation. Environmental Science and Technology, 39, $561 \quad 6881-6895$.

562 Dong, D., Yang, M., Wang, C., Wang, H., Li, Y., Luo, J., Wu, W., 2013. Responses of 563 methane emissions and rice yield to applications of biochar and straw in a paddy field. 564 Journal of Soils and Sediments, 13, 1450-1460.

565 Dunfield, P.F., 2007. The soil methane sink. In: Reay, D.S., Hewitt, N., Grace, J., 566 Smith, K.A., (Eds.) Greenhouse Gas Sinks, 152 - 170. 
567 Enders, A., Hanley, K., Whitman, T., Joseph, S., Lehmann, J., 2012. Characterization 568 of biochars to evaluate recalcitrance and agronomic performance. Bioresource 569 Technology, 114, 644-653.

570 FAO, 2014. FAOSTAT, Rome.

571 Feng, Y., Xu, Y., Yu, Y., Xie, Z., Lin, X., 2012. Mechanisms of biochar decreasing 572 methane emission from Chinese paddy soils. Soil Biology and Biochemistry, 46, 8057388.

574 Friedrich, M.W., 2005. Methyl-coenzyme M reductase genes: Unique functional 575 markers for methanogenic and anaerobic methane-oxidizing Archaea. Methods in 576 Enzymology, 428-442.

577 Fungo, B., Guerena, D., Thiongo, M., Lehmann, J., Neufeldt, H., Kalbitz, K., 2014. $578 \mathrm{~N}_{2} \mathrm{O}$ and $\mathrm{CH}_{4}$ emission from soil amended with steam-activated biochar. Journal of 579 Plant Nutrition and Soil Science, 177, 34-38.

580 Garcia, J.L., Patel, B.K.C., Olivier, B., 2000. Taxonomic, phylogenetic, and ecological 581 diversity of methanogenic archaea. Anaerobe, 6, 205-226.

582 Gattinger, A., Muller, A., Haeni, M., Skinner, C., Fliessbach, A., Buchmann, N., Mäder, 583 P., Stolze, M., Smith, P., Scialabba, N.E.H., Niggli, U., 2012. Enhanced top soil carbon 584 stocks under organic farming. Proceedings of the National Academy of Sciences, 109, $585 \quad 18226-18231$.

586 Glaser, B., Haumaier, L., Guggenberger, G., Zech, W., 2001. The 'Terra Preta' 587 phenomenon: a model for sustainable agriculture in the humid tropics. 588 Naturwissenschaften 88,37-41. DOI 10.1007/s001140000193 
Gray, M., Johnson, M.G., Dragila, M.I., Kleber, M., 2014. Water uptake in biochars:

590 The roles of porosity and hydrophobicity. Biomass and Bioenergy, 61, 196-205.

591 Grosso, S.J.D., Parton, W.J., Mosier, A.R., Ojima, D.S., Potter, C.S., Borken, W.,

592 Brumme, R., Butterbach-Bahl, K., Cril, P.M., Dobbie, K., Smith, K.A., 2000. General

$593 \mathrm{CH}_{4}$ oxidation model and comparisons of $\mathrm{CH}_{4}$ oxidation in natural and managed 594 systems. Global Biogeochemical Cycles, 14, 999-1019.

595 Gulledge, J., Doyle, A.P., Schimel, J.P. 1997. Different $\mathrm{NH}_{4}{ }^{+}$inhibition patterns of soil $596 \mathrm{CH}_{4}$ consumption: A result of distinct $\mathrm{CH}_{4}$ oxidizer populations across sites? Soil 597 Biology and Biochemistry, 29, 13-21.

598 Gurevitch, J., Morrow, L.L., Alison, W., Walsh, J.S., 1992. A meta-analysis of 599 competition in field experiments. The American Naturalist, 140, 539-572.

600 Gurwick, N.P., Moore, L.A., Kelly, C., Elias, P., 2013. A systematic review of biochar 601 research, with a focus on its stability in situ and its promise as a climate mitigation 602 strategy. PLoS ONE, 8.

603 Hanson, R.S., Hanson, T.E., 1996. Methanotrophic bacteria. Microbiol Rev., 60, 439604471.

605 Hardie, M.G.O., Bound, S., Clothier, B., Close, D., 2014. Effect of biochar application 606 on soil water availability and hydraulic conductivity, Soil. Soil Science Australia, 607 Melbourne, Australia.

608 Hedges, L.V., 1981. Distribution theory for Glass's estimator of effect size and related 609 estimators. Journal of Educational and Behavioral Statistics, 6, 107-128. 
610 Hedges, L.V., Gurevitch, J., Curtis, P.S., 1999. The meta-analysis of response ratios in 611 experimental ecology. Ecology, 80, 1150-1156.

612 Hedges, L.V., Olkin, I., 1985. Statistical Methods for Meta-Analysis. Academic Press, 613 New York, 369.

614 Hiltbrunner, D., Zimmermann, S., Karbin, S., Hagedorn, F., Niklaus, P.A., 2012. 615 Increasing soil methane sink along a 120-year afforestation chronosequence is driven 616 by soil moisture. Global Change Biology, 18, 3664-3671.

617 Holmes, A.J., Costello, A., Lidstrom, M.E., Murrell, J.C., 1995. Evidence that 618 particulate methane monooxygenase and ammonia monooxygenase may be 619 evolutionarily related. FEMS Microbiol Lett. 132, 3, 203-8.

620 Huwaldt, J.A., 2014. Plot Digitizer 2.6.6a.

621 http://sourceforge.net/projects/plotdigitizer/files/plotdigitizer/2.6.6/

622 IPCC., 2007. The Physical Science Basis. Contribution of Working Group I In: 623 Solomon, S., Qin, D., Manning, M., Chen, Z., Marquis, M., Averyt, K.B., Tignor, M., 624 Miller, H.L., (Eds.) The Fourth Assessment Report of the Intergovernmental Panel on 625 Climate Change, Cambridge, United Kingdom.

626 Jaffé, R., Ding, Y., Niggemann, J., Vähätalo, A.V., Stubbins, A., Spencer, R.G., 627 Campbell, J., Dittmar, T., 2013. Global charcoal mobilization from soils via dissolution 628 and riverine transport to the oceans. Science, 345, 7. doi: 10.1126/science.1231476.

629 Jeffery, S., Bezemer, T.M., Cornelissen, G., Kuyper, T.W., Lehmann, J., Mommer, L., 630 Sohi, S.P., van de Voorde, T.F.J., Wardle, D.A., van Groenigen, J.W., 2015. The way 
631 forward in biochar research: targeting trade-offs between the potential wins. GCB 632 Bioenergy, 7, 1-13.

633 Jeffery, S., Verheijen, F.G.A., van der Velde, M., Bastos, A.C., 2011. A quantitative 634 review of the effects of biochar application to soils on crop productivity using meta635 analysis. Agriculture, Ecosystems and Environment, 144, 175-187.

636 Kambo, H.S., Dutta, A., 2015. A comparative review of biochar and hydrochar in terms 637 of production, physico-chemical properties and applications. Renewable and 638 Sustainable Energy Reviews, 45, 359-378.

639 Kammann, C., Hepp, S., Lenhart, K., Müller, C., 2009. Stimulation of methane 640 consumption by endogenous $\mathrm{CH} 4$ production in aerobic grassland soil. Soil Biology 641 and Biochemistry, 41, 622-629.

642 Kammann, C., Ratering, S., Eckhard, C., Müller, C., 2012. Biochar and hydrochar 643 effects on greenhouse gas (carbon dioxide, nitrous oxide, and methane) fluxes from 644 soils. Journal of Environmental Quality, 41, 1052-1066.

645 Karhu, K., Mattila, T., Bergström, I., Regina, K., 2011. Biochar addition to agricultural 646 soil increased $\mathrm{CH}_{4}$ uptake and water holding capacity - Results from a short-term pilot 647 field study. Agriculture, Ecosystems and Environment, 140, 309-313.

648 Knief, C. 2015. Diversity and habitat preferences of cultivated and uncultivated aerobic 649 Methanotrophic bacteria evaluated based on $p m o A$ as molecular marker. Frontiers in 650 Microbiology 6, 01346

651 Khan, S., Chao, C., Waqas, M., Arp, H.P.H., Zhu, Y.G., 2013. Sewage sludge biochar 652 influence upon rice (Oryza sativa L.) yield, metal bioaccumulation and greenhouse gas 
653 emissions from acidic paddy soil. Environmental Science and Technology, 47, 86246548632.

655 Le Mer, J., Roger, P., 2001. Production, oxidation, emission and consumption of 656 methane by soils: A review. European Journal of Soil Biology, 37, 25-50.

657 Lehmann, J., 2007. Bio-energy in the black. Frontiers in Ecology and the Environment, $658 \quad 5,381-387$.

659 Lehmann, J., Gaunt, J., Rondon, M., 2006. Bio-char sequestration in terrestrial 660 ecosystems - A review. Mitigation and Adaptation Strategies for Global Change, 11, $661 \quad 403-427$.

662 Linquist, B.A., Adviento-Borbe, M.A., Pittelkow, C.M., van Kessel, C., van Groenigen, 663 K.J., 2012. Fertilizer management practices and greenhouse gas emissions from rice 664 systems: A quantitative review and analysis. Field Crops Research, 135, 10-21.

665 Liu, Y., Yang, M., Wu, Y., Wang, H., Chen, Y., Wu, W., 2011. Reducing $\mathrm{CH}_{4}$ and $\mathrm{CO}_{2}$ 666 emissions from waterlogged paddy soil with biochar. Journal of Soils and Sediments, $667 \quad 11,930-939$.

668 Maestrini, B., Nannipieri, P., Abiven, S., 2014. A meta-analysis on pyrogenic organic 669 matter induced priming effect. GCB Bioenergy, 7, 4, 577-590.

670 Mohan, D., Sarswat, A., Ok, Y.S., Pittman, Jr, C.U., 2014. Organic and inorganic 671 contaminants removal from water with biochar, a renewable, low cost and sustainable 672 adsorbent - A critical review. Bioresource Technology, 160, 191-202. 
673 Nazaries, L., Murrell, J.C., Millard, P., Baggs, L., Singh, B.K., 2013. Methane, 674 microbes and models: fundamental understanding of the soil methane cycle for future 675 predictions. Environmental Microbiology, 15, 2395-2417.

676 Nguyen, B.T., Lehmann, J., 2009. Black carbon decomposition under varying water 677 regimes. Organic Geochemistry, 40, 846-853.

678 Obia, A., Cornelissen, G., Mulder, J., Dorsch, P., 2015. Effect of soil pH increase by 679 biochar on NO, N2O and N2 production during denitrification in acid soils. PLOS One, 680 10, DOI: 10.1371/journal.pone.0138781.

681 Orwin, R.G., 1983. A Fail-Safe N for Effect Size in Meta-Analysis. Journal of 682 Educational Statistics, 8, 157-159.

683 Powlson, D.S., Goulding, K.W.T., Willison, T.W., Webster, C.P., Hütsch, B.W., 1997. 684 The effect of agriculture on methane oxidation in soil. Nutrient Cycling in 685 Agroecosystems, 49, 59-70.

686 Pratscher, J., Dumont, M.G., Conrad, R. 2011. Assimilation of acetate by the putative 687 atmospheric methane oxidizers belonging to the USC $\alpha$ clade. Environmental 688 Microbiology 13, 2692-2701.

689 Qian, L., Chen, B., Hu, D., 2013. Effective alleviation of aluminum phytotoxicity by 690 manure-derived biochar. Environmental Science and Technology, 47, 2737-2745.

691 Qian, T., Zhang, X., Hu, J., Jiang, H., 2013. Effects of environmental conditions on the 692 release of phosphorus from biochar. Chemosphere, 93, 2069-2075.

693 Rohatgi, A., 2016. Web Plot Ditigizer 3.10, http://arohatgi.info/WebPlotDigitizer/ 
694 Rosenberg, M.S., Adams, D.C., Gurevitch, J., 2000. MetaWin: Statistical Software for 695 Meta-Analysis Version 2.0. Sinauer Associates Inc., Massachusetts.

696 Rosenthal, R., Rosnow, R., 1991. Essentials of Behavioral Research: Methods and Data 697 Analysis. McGraw Hill, New York.

698 Rothstein, H.R., Sutton, A.J., Borenstein, M., 2005. Publication Bias in Meta-Analysis:

699 Prevention, Assessment and Adjustments. Wiley, 376.

700 Reddy, K., Yargicoglu, E., Yue, D., Yaghoubi, P., 2014. Enhanced microbial methane 701 oxidation in landfill cover soil amended with biochar. Journal of Geotechnical and 702 Geoenvironmental Engineering, 140, 04014047.

703 Roberts, K.G., Gloy, B.A., Joseph, S., Scott, N.R., Lehmann, J., 2010. Life cycle 704 assessment of biochar systems: Estimating the energetic, economic, and climate change 705 potential. Environmental Science and Technology, 44, 827-833.

706 Ronsse, F., van Hecke, S., Dickinson, D., Prins, W., 2013. Production and 707 characterization of slow pyrolysis biochar: influence of feedstock type and pyrolysis 708 conditions. GCB Bioenergy, 5, 104-115.

709 Sadasivam, B., Reddy, K., 2014. Quantifying the effects of moisture content on 710 transport and adsorption of methane through biochar in landfills, Geoenvironmental 711 Engineering, 191-200.

712 Sagrilo, E., Jeffery, S., Hoffland, E., Kuyper, T.W., 2015. Emission of $\mathrm{CO}_{2}$ from 713 biochar-amended soils and implications for soil organic carbon. GCB Bioenergy, 7, $714 \quad 1294-1304$ 
715 Schimmelpfennig, S., Müller, C., Grünhagea, L., Koch, C., Kammann, C., 2014.

716 Biochar, hydrochar and uncarbonized feedstock application to permanent grassland-

717 Effects on greenhouse gas emissions and plant growth. Agriculture, Ecosystems and

718 Environment, 191, 39-52

719 Semrau, J.D., Di Spirito, A.A., Yoon, S., 2010. Methanotrophs and copper. FEMS

720 Microbiology Reviews, 34, 496-531.

721 Serrano-Silva, N., Sarria-Guzmán, Y., Dendooven, L., Luna-Guido, M., 2014.

722 Methanogenesis and methanotrophy in soil: A review. Pedosphere, 24, 291-307.

723 Sethunathan, N., Kumaraswamy, S., Rath, A.K., Ramakrishnan, B., Satpathy, S.N., 724 Adhya, T.K., Rao, V.R., 2000. Methane production, oxidation, and emission from 725 Indian rice soils. Nutrient Cycling in Agroecosystems, 58, 377-388.

726 Singla, A., Dubey, S.K., Singh, A., Inubushi, K., 2014. Effect of biogas digested slurry727 based biochar on methane flux and methanogenic archaeal diversity in paddy soil. 728 Agriculture, Ecosystems and Environment, 197, 278-287.

729 Skinner, C., Gattinger, A., Muller, A., Mäder, P., Fließbach, A., Stolze, M., Ruser, R., 730 Niggli, U., 2014. Greenhouse gas fluxes from agricultural soils under organic and non731 organic management - A global meta-analysis. Science of Total Environment, 468$732469,553-563$.

733 Smith, P., Martino, D., Cai, Z., Gwary, D., Janzen, H., Kumar, P., McCarl, B., Ogle, 734 S., O’Mara, F., Rice, C., Scholes, B., Sirotenko, O., Howden, M., McAllister, T., Pan, 735 G., Romanenkov, V., Schneider, U., Towprayoon, S., 2007. Policy and technological 
constraints to implementation of greenhouse gas mitigation options in agriculture. Agriculture, Ecosystems and Environment, 118, 6-28. function in soil. Advances in Agronomy, 105, 47-82. on fluxes of three biogenic greenhouse gases: a meta-analysis. Ecosystem Health and

Spokas, K.A., Bogner, J.E., 2011. Limits and dynamics of methane oxidation in landfill cover soils. Waste Management, 31, 823-832.

Spokas, K.A., Reicosky, D.C., 2009. Impacts of sixteen different biochars on soil 746 greenhouse gas production. Annals of Environmental Science, 3, 179-193.

747 Stewart, C.E., Zheng, J., Botte, J., Cotrufo, M.F., 2013. Co-generated fast pyrolysis 748 biochar mitigates green-house gas emissions and increases carbon sequestration in 749 temperate soils. GCB Bioenergy, 5, 153- 164.

750 Sun, F., Lu, S., 2014. Biochars improve aggregate stability, water retention, and pore751 space properties of clayey soil. Journal of Plant Nutrition and Soil Science, 177, 26-33.

752 Sylvia, D.M., Hartel, P.G., Fuhrmann, J.J., Zuberer, D.A., 2005. Principles and 753 applications of soil microbiology, 2nd edn. Pearson, Upper Saddle, pp 41-51.

754 Tamai, N., Takenaka, C., Ishizuka, S., 2007. Water-soluble Al inhibits methane 755 oxidation at atmospheric concentration levels in Japanese forest soil. Soil Biology and 756 Biochemistry, 39, 1730-1736. 
757 Templeton, A.S., Chu, K.H., Alvarez-Cohen, L., Conrad, M.E., 2006. Variable carbon

758 isotope fractionation expressed by aerobic ch4-oxidizing bacteria. Geochimica et

759 Cosmochima Acta, 70, 1739-1752.

760 Thauer, R.K., 1998. Biochemistry of methanogenesis: a tribute to Marjory

761 Stephenson:1998 Marjory Stephenson Prize Lecture. Microbiology, 144, 2377-2406.

762 Thauer, R.K., Kaster, A.K., Seedorf, H., Buckel, W., Hedderich, R., 2008.

763 Methanogenic archaea: ecologically relevant differences in energy conservation.

764 Nature Reviews Microbiology, 6, 579-591.

765 Thomazini, A., Spokas, K., Hall, K., Ippolito, I. Novak, J. 2015. GHG impact of 766 biochar: Predictability for the same biochar. Agriculture, Ecosystems and Environment, $767 \quad 207,183-191$.

768 van Groenigen, K.J., Six, J., Hungate, B.A., de Graaff, M.A., van Breemen, N., van 769 Kessel, C., 2006. Element interactions limit soil carbon storage. Proceedings of the 770 National Academy of Sciences, 103, 6571-6574.

771 Van Zwieten, L., Kimber, S., Morris, S., Chan, K.Y., Downie, A., Rust, J., Joseph, S., 772 Cowie, A., 2010. Effects of biochar from slow pyrolysis of papermill waste on 773 agronomic performance and soil fertility. Plant and Soil, 327, 235-246.

774 Wang, J., Pan, X., Liu, Y., Zhang, X., Xiong, Z., 2012. Effects of biochar amendment 775 in two soils on greenhouse gas emissions and crop production. Plant and Soil, 360, 287776298

777 Woolf, D., Amonette, J.E., Street-Perrott, F.A., Lehmann, J., Joseph, S., 2010. 778 Sustainable biochar to mitigate global climate change. Nature Communications 1. 
779 Wu, L., Ma, K., Li, Q., Ke, X., Lu, Y., 2009. Composition of archaeal community in a 780 paddy field as affected by rice cultivar and N fertilizer. Microbial Ecology, 58, 819781826.

782 Yaghoubi, P., Yargicoglu, E., Reddy, K., 2014. Effects of biochar-amendment to 783 landfill cover soil on microbial methane oxidation: Initial results, Geo-Congress 2014 784 Technical Papers. American Society of Civil Engineers, 1849-1858.

785 Yamato, M., Okimori, Y., Wibowo, I.F., Anshori, S., Ogawa, M., 2006. Effects of the 786 application of charred bark of Acacia mangium on the yield of maize, cowpea and 787 peanut, and soil chemical properties in South Sumatra, Indonesia. Soil Science and 788 Plant Nutrition, 52, 489-495.

789 Yan, X., Akiyama, H., Yagi, K., Akimoto, H.C.G.B., 2009. Global estimations of the 790 inventory and mitigation potential of methane emissions from rice cultivation 791 conducted using the 2006 Intergovernmental Panel on Climate Change Guidelines. 792 Global Biogeochemical Cycles, 23, 1-15.

793 Zhang, A., Cui, L., Pan, G., Li, L., Hussain, Q., Zhang, X., Zheng, J., Crowley, D., 794 2010. Effect of biochar amendment on yield and methane and nitrous oxide emissions 795 from a rice paddy from Tai Lake plain, China. Agriculture, Ecosystems and 796 Environment, 139, 469-475. 
Figure 1. A forest plot of Hedge's $d$ calculated from published literature grouped by experimental water regime, soil $\mathrm{pH}$ pre-biochar amendment, $\mathrm{N}$ fertilizer application rate and biochar pyrolysis temperature. Points show means, bars show $95 \%$ confidence intervals. The numbers in parentheses indicate the number of pairwise comparisons on which the statistic is based. (For an explanation of the Hedge's $d$ metric see text).

Figure 2. A forest plot of Hedge's $d$ calculated from published literature grouped by biochar feedstock type and BET (Brunauer, Emmett and Teller) surface area. Points show means, bars show $95 \%$ confidence intervals. The numbers in parentheses indicate the number of pairwise comparisons on which the statistic is based. (For an explanation of the Hedge's $d$ metric see text). 


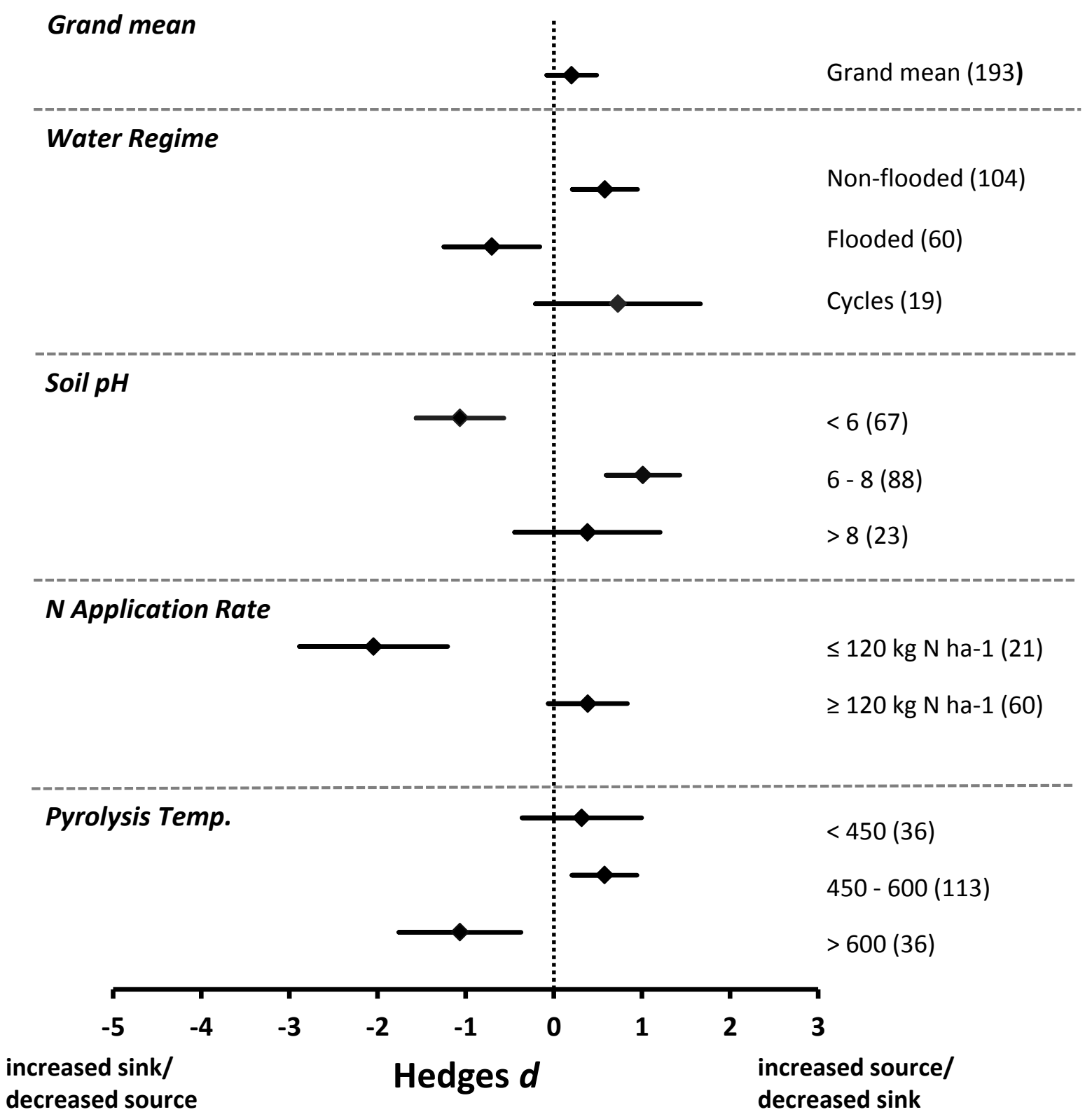




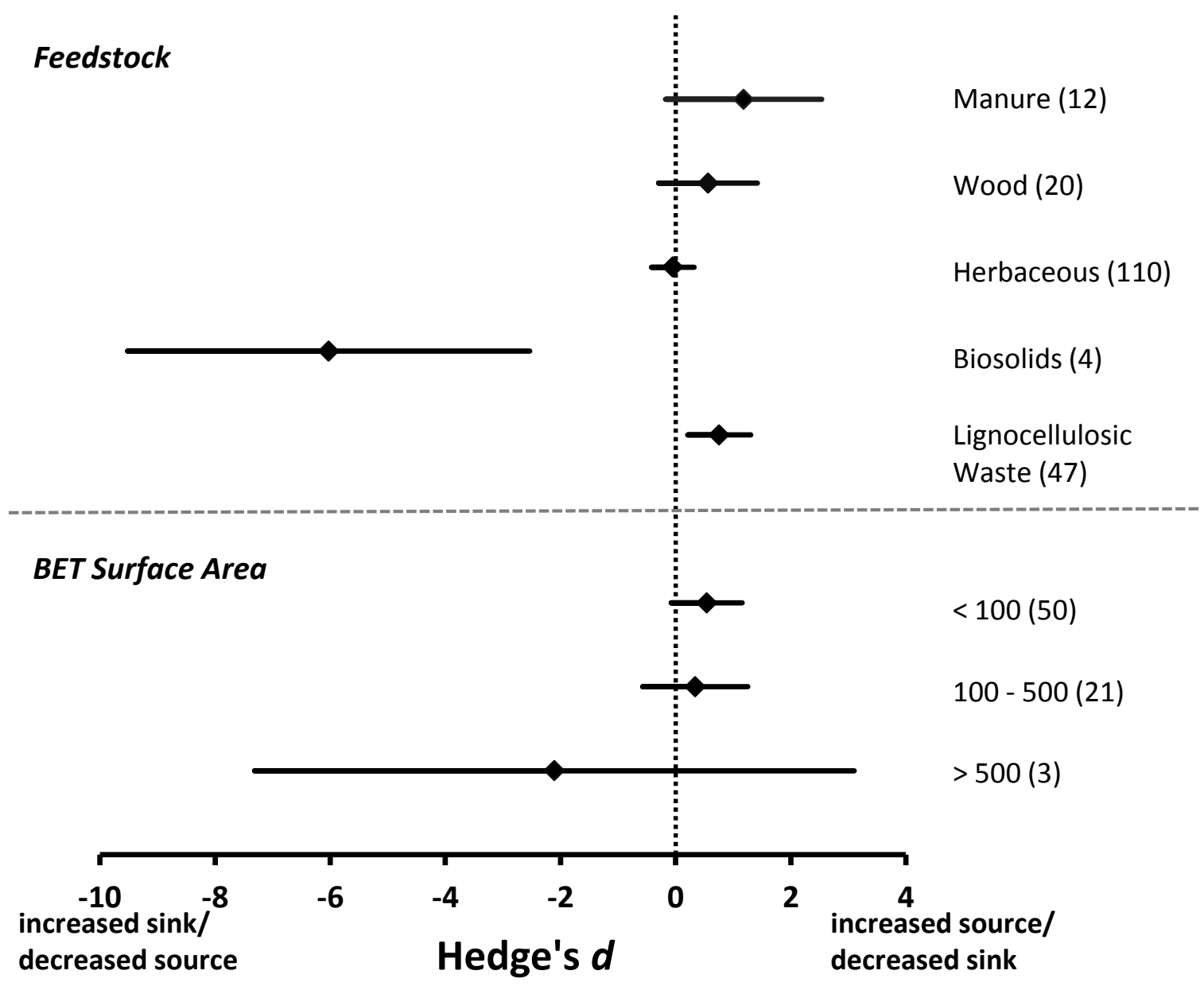




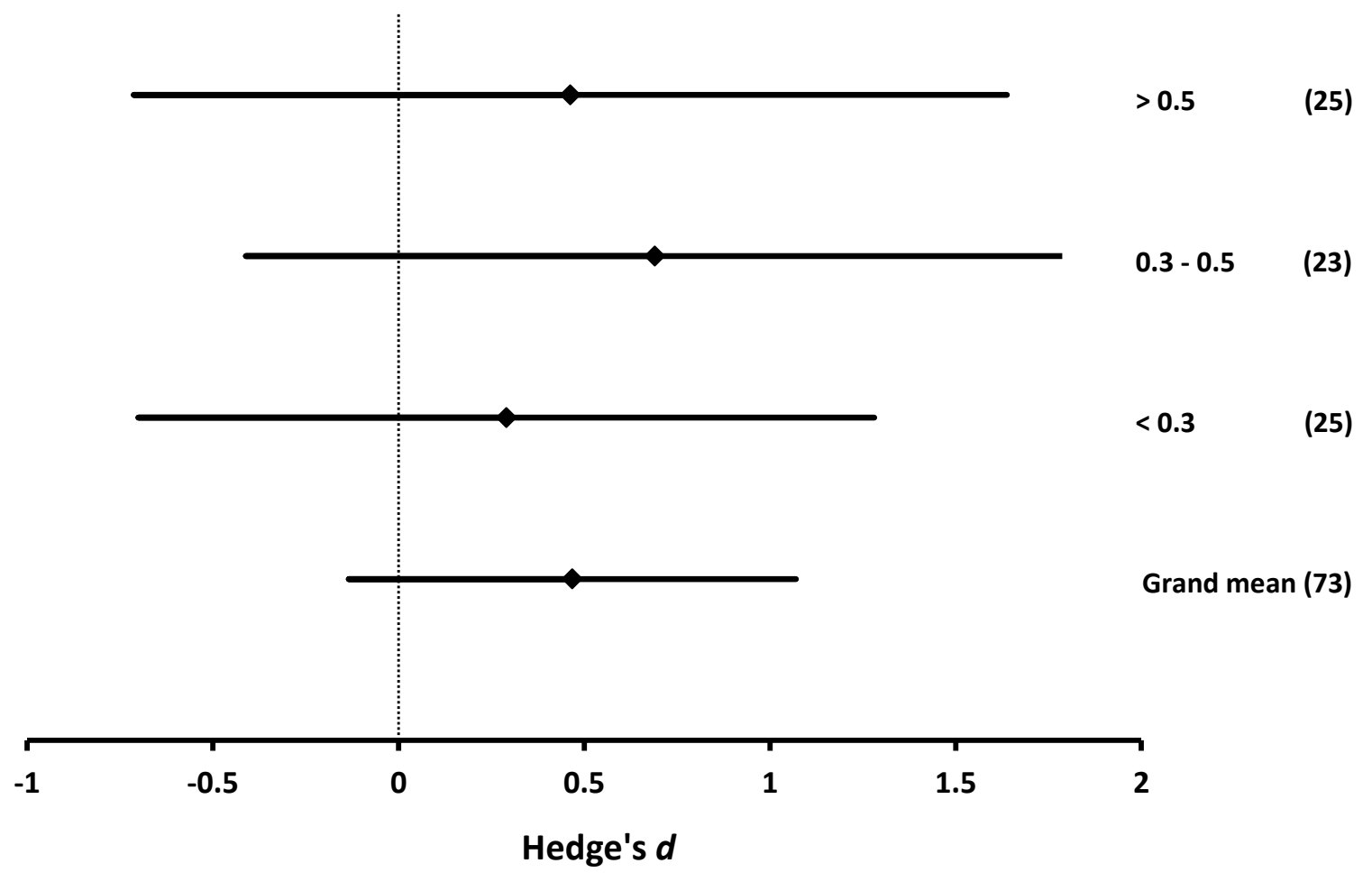


Figure S1. A forest plot of Hedge's d calculated from published literature grouped by prebiochar amendment soil $\mathrm{pH}$. The $\mathrm{pH} 5$ threshold is applied to investigate the potential effects of aluminium bioavailability/toxicity. Points show means, bars show $95 \%$ confidence intervals. The numbers in parentheses indicate the number of pairwise comparisons on which the statistic is based. (For an explanation of the Hedge's $d$ metric see text).

Figure S2. A forest plot of Hedge's $d$ calculated from published literature grouped by H:Corg. Points show means, bars show 95\% confidence intervals. The numbers in parentheses indicate the number of pairwise comparisons on which the statistic is based. (For an explanation of the Hedge's $d$ metric see text). 
Table S1. A list of the studies included in the meta-analysis database.

\begin{tabular}{|c|c|c|c|c|c|c|c|}
\hline Reference & Country & Soil $p H$ & Water regime & $\begin{array}{c}\text { BET surface } \\
\text { area }\end{array}$ & $\begin{array}{c}\text { Pyrolysis } \\
\text { temperature }\end{array}$ & H:Corg & $\begin{array}{l}\text { Biochar } \\
\text { feedstock }\end{array}$ \\
\hline Castaldi et al., 2011 & Italy & $<6$ & Non-flooded & - & $450-600$ & - & Wood \\
\hline Dong et al., 2013 & China & $<6$ & Flooded & $<100$ & $>600$ & $0.3-0.5,>0.5$ & Herbaceous \\
\hline Feng et al., 2012 & China & $6-8$ & Flooded & - & $<450,450-600$ & - & Herbaceous \\
\hline Fungo et al., 2014 & Kenya & $6-8$ & Non-flooded & - & $<450,450-600$ & $0.3-0.5,>0.5$ & Herbaceous \\
\hline Khan et al., 2013 & China & $<6$ & Flooded & $<100$ & $450-600$ & - & Biosolids \\
\hline Liu et al., 2011 & China & $<6$ & Flooded & - & $>600$ & $0.3-0.5,>0.5$ & Herbaceous \\
\hline Scheer et al., 2011 & Australia & $<6$ & Non-flooded & - & $450-600$ & $>0.5$ & Herbaceous \\
\hline Singla and Inubushi, 2014 & Japan & $<6$ & Flooded & - & $<450$ & - & Manure \\
\hline Spokas et al., 2009 & USA & $6-8$ & Flooded & $<100$ & $450-600$ & $0.3-0.5$ & Lignocellulosic \\
\hline Wang et al., 2012 & China & $6-8$ & Flooded & - & $450-600$ & - & Lignocellulosic \\
\hline Wu et al., 2013 & Canada & $<6$ & Non-flooded & - & $450-600$ & $0.3-0.5$ & Herbaceous \\
\hline Xie et al., 2013 & China & $6-8$ & Cycles & - & $<450$ & - & Herbaceous \\
\hline Zhang et al., 2012 & China & $6-8$ & Cycles & $<100$ & $450-600$ & - & Herbaceous \\
\hline Zhang et al., 2012 & China & $>8$ & Non-flooded & $<100$ & $450-600$ & - & Herbaceous \\
\hline Zhang et al., 2010 & China & $6-8$ & Flooded & $<100$ & $450-600$ & - & Herbaceous \\
\hline Zheng et al., 2012 & USA & $6-8,>8$ & Non-flooded & $100-500$ & $450-600$ & $<0.3$ & Lignocellulosic \\
\hline Liu et al., 2014 & China & $<6$ & Flooded & - & $450-600$ & - & Herbaceous \\
\hline Pandey et al., 2014 & Vietnam & - & Cycles & - & - & - & Herbaceous \\
\hline $\begin{array}{l}\text { Schimmelpfennig et al., } \\
2014\end{array}$ & Germany & $<6$ & Non-flooded & $>500$ & $>600$ & $<0.3$ & Herbaceous \\
\hline Shen et al., 2014 & China & $<6$ & Flooded & - & - & - & Herbaceous \\
\hline Singla et al., 2014 & Japan & $6-8$ & Flooded & - & $<450$ & $>0.5$ & Manure \\
\hline Zhao et al., 2014 & China & $6-8$ & Flooded & - & $450-600$ & - & Herbaceous \\
\hline Zhang et al., 2014 & Canada & $6-8$ & Non-flooded & - & $>600$ & - & Lignocellulosic \\
\hline
\end{tabular}




\begin{tabular}{|c|c|c|c|c|c|c|c|}
\hline Zhang et al., 2013 & China & $6-8$ & Cycles & $<100$ & $450-600$ & - & Herbaceous \\
\hline Jia et al., 2012 & China & $<6$ & Non-flooded & - & $<450$ & - & Herbaceous \\
\hline Ali et al., 2013 & Bangladesh & $6-8$ & Cycles & - & $450-600$ & - & Lignocellulosic \\
\hline Spokas et al., 2013 & USA & $6-8$ & Non-flooded & $<100$ & $450-600$ & $<0.3,0.3-0.5$ & Lignocellulosic \\
\hline Angst et al., 2014 & USA & $6-8$ & Non-flooded & $<100$ & $450-600$ & $>0.5$ & Lignocellulosic \\
\hline Case et al., 2014 & UK & $6-8$ & Non-flooded & - & $<450$ & - & Lignocellulosic \\
\hline Li et al., 2013 & China & $<6,>8$ & - & $<100$ & $<450,450-600$ & - & Herbaceous \\
\hline Ly et al., 2014 & Cambodia & $<6$ & Flooded & - & $450-600$ & - & Herbaceous \\
\hline Stewart et al., 2013 & USA & $>8$ & Non-flooded & $100-500$ & $450-600$ & $<0.3$ & Lignocellulosic \\
\hline Watanabe et al., 2014 & Japan & - & Non-flooded & - & $>600$ & - & Herbaceous \\
\hline Karhu et al., 2011 & Finland & - & Non-flooded & $<100$ & $<450$ & - & Lignocellulosic \\
\hline Troy et al., 2013 & Ireland & $6-8$ & Non-flooded & - & $>600$ & - & Manure \\
\hline Mukherjee et al., 2014 & USA & $6-8$ & Non-flooded & $100-500$ & $>600$ & - & Wood \\
\hline Thomazini et al., 2015 & USA & $<6,6-8$ & Non-flooded & $<100$ & $450-600$ & - & Wood \\
\hline Vu et al., 2015 & Vietnam & $<6$ & Cycles & - & - & - & Herbaceous \\
\hline Zhang et al., 2015 & China & $6-8$ & Cycles & $<100$ & $450-600$ & - & Herbaceous \\
\hline Li et al., 2015 & China & $<6$ & Non-flooded & $<100$ & $<450$ & - & Herbaceous \\
\hline Lin et al., 2015 & China & $>8$ & Non-flooded & - & $<450$ & - & Herbaceous \\
\hline Yoo et al., 2015 & Korea & $<6,6-8$ & Flooded & - & $<450,>600$ & $0.3-0.5,>0.5$ & Herbaceous \\
\hline Yu et al., 2013 & China & $<6$ & $\begin{array}{l}\text { Non-flooded, } \\
\text { Flooded }\end{array}$ & - & - & $>0.5$ & Manure \\
\hline
\end{tabular}


Supplementary Table S2. Between-group heterogeneity $\left(\mathrm{Q}_{\mathrm{b}}\right)$, within-group heterogeneity $\left(\mathrm{Q}_{\mathrm{w}}\right)$ and total heterogeneity $\left(\mathrm{Q}_{\mathrm{t}}\right)$.

\begin{tabular}{lccc}
\hline & $\mathbf{Q}_{\mathbf{b}}$ & $\mathbf{Q}_{\mathbf{w}}$ & $\mathbf{Q}_{\mathbf{t}}$ \\
\hline Water regime & $16.55 * * *$ & $342.32 * * *$ & $358.88 * * *$ \\
Soil pH & $40.92 * * *$ & $324.99 * * *$ & $365.92 * * *$ \\
N application rate & $27.76 * * *$ & $117.67 * *$ & $145.44 * * *$ \\
Pyrolysis temperature & $17.98^{* * *}$ & $349.95 * * *$ & $367.93 * * *$ \\
Feedstock & $41.46 * * *$ & $348.31 * * *$ & $389.77 * * *$ \\
BET Surface Area & 5.41 & $148.12 * * *$ & $153.54 * * *$ \\
Soil pH - cut off at pH 5 & $6.45^{*}$ & $350.41 * * *$ & $356.86 * * *$ \\
H: $C_{\text {org }}$ molar ratio & 0.31 & $180.76 * * *$ & $181.07 * * *$ \\
Soil texture & $7.76^{*}$ & $238.73 * * *$ & $246.49 * * *$ \\
\hline
\end{tabular}

${ }^{*} \mathrm{p}<0.05 ; * * \mathrm{p}<0.01 ; * * * \mathrm{p}<0.001$ 